\title{
Editor's Message: Understanding the Sacroiliac Joint
}

\author{
DAVID W. POLLY JR, MD \\ Professor and Chief of Spine Service, Department of Orthopedic Surgery, University of Minnesota Medical School, M Health Clinics and Surgery Center, \\ Minneapolis, Minnesota
}

The sacroiliac joint is the source of low back pain in $15 \%$ to $30 \%$ of patients. ${ }^{1}$ In patients who have had a fusion to the sacrum it is even higher. There has been increasing interest in this topic from surgeons. Recent clinical trials ${ }^{2,3}$ have demonstrated good outcomes with surgical intervention.

To provide additional insight on this important and challenging topic, the International Journal of Spine Surgery has compiled this focus issue. The articles include a summary of the biomechanics of the sacroiliac joint, a review of non-operative management options, a review of diagnostic and therapeutic injections, as well as reviews of the clinical and surgical implications of abnormal lumbosacral anatomy and surgical clinical trial data.

We hope you find this focus issue to be in a convenient compilation of information regarding the sacroiliac joint. There is still much work to be done on this topic, but the progress over the past 5 years has been substantial.

\section{REFERENCES}

1. Ramirez C, Sanchez L, Oliveira B. Prevalence of sacroiliac joint dysfunction and sacroiliac pain provocation tests in people with low back pain. Ann Phys Rehabil Med. 2018;61(suppl):e152.

2. Dengler J, Kools D, Pflugmacher R, et al. Randomized trial of sacroiliac joint arthrodesis compared with conservative management for chronic low back pain attributed to the sacroiliac joint. J Bone Joint Surg Am. 2019;101(5):400-411. https://doi.org/10.2106/JBJS.18.00022

3. Polly DW, Swofford J, Whang PG, et al; INSITE Study Group. Two-year outcomes from a randomized controlled trial of minimally invasive sacroiliac joint fusion vs. non-surgical management for sacroiliac joint dysfunction. Int J Spine Surg. 2016;10:28. https://doi.org/10.14444/3028

Disclosures and COI: Consulting fees: SI Bone; Springer textbook royalties; Medtronic; Globus Medical.

Published 10 February 2020

This manuscript is generously published free of charge by ISASS, the International Society for the Advancement of Spine Surgery. Copyright (C) 2020 ISASS. To see more or order reprints or permissions, see http://ijssurgery.com. 